\title{
The effect of short online pedagogical training on university teachers' interpretations of teaching-learning situations
}

\author{
Henna Vilppu ${ }^{1}$ (D) $\cdot$ Ilona Södervik $^{1,2} \cdot$ Liisa Postareff $^{3} \cdot$ Mari Murtonen $^{1,4}$
}

Received: 9 August 2018 / Accepted: 24 September 2019 / Published online: 23 October 2019

(c) The Author(s) 2019

\begin{abstract}
The aim of the study was to explore whether short online pedagogy courses can have an effect on university teachers' interpretations of teaching-learning situations. Before and after participating in a short online pedagogical training programme, a total of 66 participants wrote their interpretations of two short video clips, which depicted a content-focused teacher and a learning-focused teacher, respectively. The training was successful in changing participants' interpretations from a knowledge-transmission view to a learning-facilitation view of teaching. This result indicates that even short online training programmes have the potential to affect participants' interpretations of teaching-learning situations, especially when participants are not very experienced in teaching. Therefore, pedagogical training should be offered already at the early stages of teaching careers.
\end{abstract}

Keywords Conceptions of teaching · Faculty development · Higher education · Online pedagogical training $\cdot$ Pre-tests $\cdot$ Post-tests

\section{Introduction}

The quality of higher education teaching has received increasing attention, both nationally and internationally, in recent years. For example, the European Commission has highlighted the importance of improving the status and quality of higher education teaching, which has traditionally been less valued than research output (European Commission 2016). In Finland, many universities offer pedagogical training for teachers; in most cases, however, participation is voluntary. Furthermore, the challenge for university pedagogy courses has been that they have been available only to staff members who can participate in relatively lengthy, face-to-face sessions while at the same time fulfilling their teaching duties at the university (Laato et al. 2018). In addition, supply has not always met demand

Henna Vilppu

henna.vilppu@utu.fi

1 Department of Teacher Education, University of Turku, Assistentinkatu 5, 20014 Turku, Finland

2 University of Helsinki, Helsinki, Finland

3 Häme University of Applied Sciences, Hämeenlinna, Finland

4 University of Tampere, Tampere, Finland 
as many universities lack the resources to offer university pedagogical training. These reasons have led to a situation where, for example, doctoral students who are not teaching at the time they apply have not been eligible for the courses, or new faculty have not been selected because more experienced faculty fill the available spots. This has perpetuated the traditional convention for new faculty to begin teaching at the university without any pedagogical training (Knight 2002).

Offering low-threshold, easily reachable, timely pedagogical support to current and future staff, such as doctoral students, before their first teaching tasks commence, could be beneficial in many ways. Such support aims at developing a teacher identity and preventing new faculty from adopting the methods by which they were taught without purposefully developing teaching skills (Knight 2002). In addition, the commonly held feeling of not getting support from colleagues and the institution when starting as a university teacher could be reduced (Ambrose et al. 2005). The experiences of new faculty are important to the formation of the university teaching culture and improving the quality of teaching (Van Lankveld et al. 2017). Pedagogical training emphasises the role of collegial collaboration and may help in creating communities of practice that enable discussions about teaching with colleagues and the reduction of academic isolation (Remmik et al. 2011). Furthermore, participating in pedagogical training not only helps teachers understand the teaching-learning process, which is crucial for planning and teaching courses, but also strengthens teachers' self-efficacy beliefs (Postareff et al. 2007). Solutions that offer timely support for new teachers, however, are scarce. In addition, the length of the pedagogical training required to have an impact on teachers' conceptions or practices has been discussed. Doubts have been raised about the efficacy of short pedagogical training programmes lasting less than six months to one year (e.g., Chalmers and Gardiner 2015; Stes et al. 2010; Ödalen et al. 2018). However, the question remains as to what types of improvements, if any, can be made with short training programmes.

The aim of this study was to explore whether short online courses can have an effect on university teachers' interpretations of teaching. To avoid the problems of traditional selfreport studies, we chose video assessment as the method for studying teachers' interpretations of teaching situations.

\section{Teachers' conceptions of and approaches to teaching}

High-quality teaching fosters active, self-regulated and collaborative learning (e.g., Vermunt et al. 2017). To achieve this goal, teachers should fulfil the role of expert in initiating and guiding students' learning processes instead of merely transmitting knowledge to students. In other words, teachers' approaches to teaching should be learning-focused instead of content-focused. The learning-focused approach to teaching refers to a teaching method in which the teacher's intention is to facilitate students' deep learning processes through activating students' knowledge construction (Postareff and Lindblom-Ylänne 2008; Trigwell et al. 1999). Students are seen as active agents in the teaching-learning process, and interaction between the teacher and the students, as well as among students, is seen as a key element of teaching. In the content-focused approach to teaching, the teacher's intention is to transmit knowledge to the students in a manner that does not address activating the students. Thus, students are not encouraged to actively construct their own understanding, and the importance of interaction is not acknowledged. The content-focused approach to teaching is associated with the adoption of the surface approach to learning among students, while the learning-focused approach to teaching encourages students to adopt a deep 
approach to learning (Trigwell et al. 1999; Uiboleht et al. 2018). The surface approach to learning refers to unreflective studying, which is likely to lead to a fragmented knowledge base (Lindblom-Ylänne et al. 2018). The deep approach to learning, in contrast, refers to a reflective and critical approach to studying, which often results in a coherent understanding of the phenomenon under study (Entwistle 2009).

Teachers' approaches to teaching have been shown to be influenced by teachers' conceptions of teaching (Kember and Kwan 2000; Trigwell and Prosser 1996a). According to Postareff and Lindblom-Ylänne (2008), approaches to teaching are defined as the strategies teachers adopt for their teaching, whereas conceptions of teaching are defined as beliefs teachers have about teaching that underlie the purpose and the strategies of teaching. Thus, while approaches to teaching give us information about how a teacher would likely act in a teaching situation, conceptions give us information about why they would do certain things. According to Bullough and Knowles (1991), the conceptions about learning and teaching form lenses through which teachers interpret teaching. A set of conceptions concerning teaching can be seen as a framework theory that affects a teacher's approach to teaching and interpretation of issues related to teaching. According to Vosniadou and Skopeliti (2014), a framework theory can be used as a basis for the explanation and prediction of everyday phenomena. In a teacher's work, this means the conceptions the teacher holds form a framework theory the teacher can use in explaining and predicting teaching situations.

University teachers' conceptions of teaching have been found to vary from teaching as transmitting knowledge from the teacher to the students to teaching as facilitating learning, that is, by constructing knowledge with the students to achieve conceptual change (Kember and Kwan 2000; Prosser et al. 1994; Samuelowicz and Bain 1992, 2001). The conception of teaching as knowledge transmission refers to the idea that teachers consider their most important teaching task to be offering information to students. Thus, teachers focus on delivering information, producing materials, keeping timetables to ensure all planned topics are addressed in a lecture and covering all that is known about the subject. Such teaching is targeted mainly at individual learners because the teacher sees no value in collaborative processes, except perhaps in terms of entertainment. Contrarily, teachers who aim at fostering learning consider the most important teaching task to be supporting students' learning processes and creating the learning environment in a way that scaffolds learning activities. The construction of collaborative knowledge is at the centre of the activity, and the goal is to enhance conceptual change. The construction of knowledge can also be referred to as knowledge creation (Paavola et al. 2004). In the knowledge creation metaphor, learning is targeted at incomplete, open-ended epistemic objects; these objects constantly generate novel questions and become increasingly complex when pursued (Knorr-Cetina 1999). A teacher using the knowledge creation approach considers the following issues in teaching: (1) creating possibilities for building and extending shared knowledge artefacts (ideas, theories, products, etc.); (2) creating collectively shared knowledge practices that aim at creating innovation and novel social practices; and (3) fostering the transactive development of expertise, meaning the interaction of personal and collaborative knowledge-creating efforts (Murtonen and Lehtinen in press; Paavola et al. 2004).

An underlying consistency between teachers' beliefs and intentions has been widely reported (e.g., Dunkin 1990; Fox 1983; Norton et al. 2005; Pratt 1992; Sherman et al. 1987). Thus, teachers who hold a particular conception of teaching tend to adopt a corresponding approach to teaching (Trigwell and Prosser 1996a; Kember and Kwan 2000). Teachers who perceive teaching primarily as a process of transmitting knowledge tend to adopt a content-focused approach to teaching. They are also more likely to focus on 
the whole class and give examples and illustrations from their own experiences. Teachers who conceive of teaching as helping students to construct their own understanding, on the other hand, tend to adopt a learning-focused approach to teaching. They tend to encourage students to discover knowledge on their own through interaction, address the needs of individual students and utilise the students' experiences in their teaching. However, some teachers have been shown to describe approaches to teaching that are more content-focused than could be expected from their reported conceptions of teaching. Still, the correspondence between conceptions and approaches has been shown to be around 90\% (Kember and Kwan 2000).

Both the theories of teaching approaches and the conceptions of teaching have established that the major categories of learning-focused approaches are related to conceptual change, and content-focused approaches are related to knowledge transmission. However, it is worth noting the relationship between them is not exclusive and should not be perceived as an either/or relationship. Instead, teachers may adopt elements of both approaches in their teaching and hold conceptions that mirror elements of both conception categories (see Åkerlind 2003; Postareff and Lindblom-Ylänne 2008). Some teachers may adopt a purely content- or learning-focused approach to teaching and hold conceptions that reflect only the knowledge transmission or conceptual change elements, respectively; other teachers may combine elements of both categories in their teaching (Postareff et al. 2008a; Uiboleht et al. 2016). Furthermore, there might sometimes even be a disjunction between teachers' conceptions of teaching and their claimed educational practice (Murray and Macdonald 1997; Norton et al. 2005; Samuelowicz and Bain 1992).

Many studies have suggested that approaches to teaching will not necessarily develop if the associated conceptions do not change or develop (Ho et al. 2001; Trigwell and Prosser 1996b). However, scholars have also suggested that conceptions of teaching may develop only if there is a change to more sophisticated approaches to teaching (see Guskey 2002), suggesting that changes in the conceptions of teaching require changes in the approaches to teaching. Whatever the direction of the relationship, it is evident that approaches to teaching and conceptions of teaching must become more learning-focused.

Previous research has shown there are disciplinary differences in the approaches to teaching and the conceptions of teaching. Since different disciplines are taught in different departments, variations in teaching might result from variations in the departmental context (Knight 2002; Knight and Trowler 2000). Disciplines have been shown to be related to the teachers' approaches, such that natural science teachers are more content-focused in their teaching, and their colleagues in the humanities are more learning-focused (LindblomYlänne et al. 2006; Lueddeke 2003; Trigwell 2002). According to Norton et al. (2005), the academic environment also has an impact on conceptions of teaching. In their study, science teachers scored lower on interactive teaching than arts or social sciences teachers, but achieved significantly higher scores on some subscales of knowledge transmission beliefs than arts and social sciences teachers. Conceptions of teaching seemed to vary between different disciplines, but not between teachers in the same discipline at different institutions (Norton et al. 2005). Samuelowicz and Bain (2001) argued that staff in different disciplines had undergone different socialisation processes as teachers, which might result in different conceptions of teaching (see also Blomberg et al. 2011). 


\section{The importance of pedagogical support}

The first years in academic work can be challenging in many ways. Although academics are often well prepared for the research role, many have little or no formal preparation for the teaching role (Kane et al. 2002; Knight 2002). If time and pedagogical support are lacking, new teachers may simply adopt their own teachers' teaching style despite knowing it might not be the best way to promote student learning (Knight 2002). Although Oleson and Hora (2014) pointed out that teaching the way they were taught can be also positive in terms of acknowledging and building upon older faculty's previous cultural knowledge, the use of previous practices should be done purposefully. If the teaching culture is supportive, and colleagues help novices to plan and implement teaching, the use of previous practices can foster teachers' pedagogical development and promote teaching quality. However, if there is no support, just doing things as they have always been done does not develop practices or teachers' expertise. Such a lack of pedagogical awareness is often related to content-focused rather than learning-focused teaching conceptions and approaches to teaching (Postareff and Lindblom-Ylänne 2008).

The research results are somewhat conflicting with regard to changing or developing university teachers' conceptions of teaching and teaching practices through pedagogy courses. While Norton et al. (2005) reported no significant differences in the beliefs or intentions of trained and untrained teachers, other studies have more positive implications. For example, in a study by Light and Calkins (2008), conceptions of teaching either remained unchanged or mostly changed in a more student- or learning-centred direction; no negative variation (change to a less student- or learning-centred direction) was detected after a yearlong faculty development program. Additionally, Ho et al. (2001) achieved promising results concerning the change in conceptions in a month-long programme. It has been suggested, however, that profound changes in teaching practices require courses of relatively long duration. After one year of pedagogical training, teachers reported they used more learning-focused approaches to teaching and had stronger self-efficacy beliefs (Postareff et al. 2007). Moreover, these changes were relatively stable after two years. Interestingly, after six months of pedagogical training, teachers reported decreased adoption of learning-focused approaches to teaching and lower self-efficacy beliefs than before any training; this is likely due to the teachers' increased pedagogical awareness (Postareff et al. 2007, 2008b).

Teachers with extensive teaching experience are more likely to be reluctant to change teaching conceptions or practices than teachers with less teaching experience (Postareff and Nevgi 2015). Being an expert in one field may prevent developing expertise in other fields, especially if one does not accept that one might be a novice in that field (see Akkerman and Bakker 2011). To develop pedagogical expertise, teachers must cross the boundaries between their own subject domain and the domain of pedagogical theories and knowledge (see Akkerman and Bakker 2011). This might be especially challenging for more experienced teachers. When participating in a pedagogical development course, teachers are challenged by new theories of teaching and learning, and they are involved in a continuous process of going beyond the boundaries of their own discipline and pedagogical field (Postareff and Nevgi 2015). 


\section{Organisation of pedagogical training in universities}

There is an urgent need in Europe to modernise higher education, in which improving the quality of teaching plays a major role (European Commission 2016). Despite this need and many initiatives in its regard, teaching in universities is sometimes still viewed as an activity that requires no formal preparation (Stewart 2014).

However, pedagogical training is increasingly offered to university staff in many countries. The most common model of teaching development for university academics is the part-time, year-long course prevalent in northern Europe, the United States (US), Canada and Australia (Stewart 2014). In the United Kingdom (UK), for example, these courses are increasingly mandatory for new staff at the beginning of their academic career; however, in many countries, attending these courses is still voluntary. In Finland, pedagogical training has been systematically organised since the 1990s. Currently, all Finnish universities offer pedagogical training for those who are willing to participate, and at some universities, the training is mandatory (Murtonen and Ponsiluoma 2014). In most Finnish universities, it is possible to take at least ten European credit transfer and accumulation system (ECTS) credits of university pedagogy, and the largest universities offer up to 60 ECTS credits (the same amount of pedagogical training required for other educational levels in Finland). Despite the increased supply of pedagogy courses, many Finnish universities have faced demands for a greater number of pedagogy courses and more flexible forms of such training for broader participant groups, such as doctoral students and researchers, who are not currently teaching (and thus cannot apply for traditionally organised, face-to-face pedagogical training). This demand has led to the development of a national online learning platform for university pedagogical support, the University pedagogical support (UNIPS), which is open to all university staff and doctoral students for self-study and one-credit guided study courses (Laato et al. 2018). Guided study differs from self-study in that in addition to self-study materials, guided study courses utilise online discussions to create knowledge collaboratively and improve pedagogical expertise. Developed originally at the University of Turku in 2015, the guided study modules in this environment have been completed more than 500 times within a three-year period (see Laato et al. 2018).

There is growing interest in researching the effects and effectiveness of higher education pedagogical training (Ödalen et al. 2018). Overall, the research seems to indicate that the effects of such training are positive but usually rather small (cf. Stes et al. 2012; Trigwell et al. 2012). According to Stes et al. (2010), instructional development interventions that extend over time have more positive behavioural outcomes than one-time events. Successful professional development programmes are collaborative, reflective and of long duration. Instead of being isolated workshops, the programmes are tightly integrated into everyday teaching practice (Teräs 2016). In the era of digitalisation, these programmes are organised online with increasing frequency. Although research that addresses implementing these kinds of professional development programmes online is scarce, there is encouraging evidence that online courses can be successful if they promote the development of self-regulation skills and facilitate collaborative learning (see Teräs 2016). For example, in a study by Rienties et al. (2013), academics' intentions to merely transmit knowledge decreased after they had completed an online teacher training programme. 


\section{Aim of the research}

Previous research has shown that teachers' conceptions of teaching are connected to their approaches to teaching (e.g., Trigwell and Prosser 1996a), which further affect students' learning (e.g., Trigwell et al. 1999). Teachers' conceptions form lenses through which they interpret teaching (Bullough and Knowles 1991), and a set of conceptions form a framework theory that the teachers use in explaining teaching situations (Vosniadou and Skopeliti 2014). In this study, we aimed to study teachers' interpretations or explanations of teaching situations in order to understand their thinking. We assumed their interpretations reflected their conceptions of teaching at some level.

We explored whether university teachers' interpretations of teaching can be affected during a short online pedagogy course. We utilised a video-based approach to study teachers' interpretations and changes in them. Teachers were shown video clips of teaching-learning situations that they were asked to interpret in written format. This was executed both at the beginning and at the end of the short online university pedagogy courses. We were also interested in what other factors might be connected to the change or the stability of the interpretations. These factors were faculty, status (teacher/doctoral student) of the participant, previous pedagogical education, teaching experience and the total number of short online pedagogy courses taken during the measurement.

\section{Method}

\section{Participants}

The participants were students of a university pedagogical training programme organised in an online UNIPS learning platform. At the university where these data were collected, it is not obligatory for teachers to participate in pedagogical training. Thus, the participants were voluntarily enrolled in the training. Voluntary participation, informed consent, and anonymity of the participants were ensured in the research process. The study did not involve intervention in the physical integrity of the participants, deviation from informed consent, studying children under the age of 15 without parental consent, exposure to exceptionally strong stimuli, causing long-term mental harm beyond the risks of daily life, or risking participants' security (cf. Finnish Advisory Board on Research Integrity 2019). Consequently, this study did not require a Finnish ethics review.

A total of 76 students participated in the training programme. Of them, 10 (13\%) declined to participate to the study, and their answers were removed from the data. Thus, 66 respondents participated in the study's pre-test; of these, 53 participated in the post-test. The respondents comprised 21 (32\%) university teachers, 21 (32\%) doctoral students who had teaching duties and 24 (36\%) doctoral students who did not have any teaching duties at the university. The doctoral students without teaching duties were considered here to be prospective teachers who might be given teaching duties in the near future. Of the participants, $22(33 \%)$ were male and $44(67 \%)$ female. The participants represented seven faculties; however, to guarantee participants' anonymity, the faculties were grouped into two larger entities: the social sciences and humanities $(\mathrm{n}=21)$ and the natural sciences, law, and economics $(\mathrm{n}=44)$. 
A total of $33 \%$ of the participants $(n=22)$ had previous education in (university) pedagogics or education. The previous pedagogical education varied from a one-credit ECTS course to a classroom teaching degree (master's degree). During the data collection portion of this study, each participant took part in a voluntary pedagogical training programme over five weeks, comprising one to three simultaneously organised university pedagogy courses (one ECTS credit each): 21 (32\%) participants took only one course, 15 (23\%) took two of the three courses and $30(46 \%)$ took all three simultaneously offered courses. Most participants were new faculty at the university, with fewer than two years of work experience at the university (see Table 1). Additionally, most participants were novices in university teaching as during the time they had worked at the university they had been teaching for fewer than two years.

\section{Description of the online UNIPS study environment and content of the three modules}

As discussed, the study took place using an online learning platform called UNIPS (unips. fi). The UNIPS platform is a collaborative project of eight Finnish universities (out of a total of 13 universities in Finland), funded by the Finnish Ministry of Education and Culture from 2017 to 2019. The project was based on a previous project named "University of Turku Pedagogical Support" (UTUPS; see Laato et al. 2018), in which the first version of the environment was created. At the time this paper is written, UNIPS comprises around ten short courses, called modules (each bearing one ECTS credit), which the participating universities can utilise in their academic training. The platform focuses on producing highquality learning material in higher education and provides easy access to that material for university staff members. The materials are freely available, so that university teachers can get information and support for their teaching whenever they need through self-study. Furthermore, guided study with credit points is offered regularly, which utilises online group discussions in addition to the self-study materials. A secondary focus of the platform is offering university pedagogical studies for doctoral students, who traditionally have not been eligible for university pedagogical training (Laato et al. 2018).

The UNIPS platform is built on the WordPress content management system (CMS) and, at the time of the study, consisted of three separate pedagogical modules which each comprised two phases: an individual study phase and a small-group phase. During the

Table 1 Participants' work and teaching experience at the university

\begin{tabular}{llllllll}
\hline $\begin{array}{l}\text { Work experience at } \\
\text { the university }\end{array}$ & \multicolumn{2}{l}{ Teaching experience at the university* } & & \\
\cline { 2 - 7 } & No experience & $0-2$ years & $2-5$ years & $5-10$ years & $10-15$ years & $\begin{array}{l}\text { More } \\
\text { than } \\
15 \text { years }\end{array}$ & Total \\
\hline 0-2 years & 12 & 12 & 0 & 0 & 0 & 0 & 24 \\
2-5 years & 5 & 6 & 7 & 1 & 0 & 0 & 19 \\
5-10 years & 1 & 3 & 4 & 6 & 0 & 0 & 14 \\
10-15 years & 0 & 0 & 1 & 1 & 0 & 0 & 2 \\
More than 15 years & 2 & 2 & 0 & 1 & 1 & 1 & 7 \\
Total & 20 & 23 & 12 & 9 & 1 & 1 & 66 \\
\hline
\end{tabular}

*In at least one course per academic year 
individual phase, the participants studied the self-study materials (e.g., videos, journal articles, glossaries and quizzes). Then, based on the materials, they wrote an essay reflecting their own thoughts about the themes of the materials. The materials were designed to be engaging, entertaining and informative. Thus, they included interactive elements that activated the learners. In the small-group phase, the participants were divided into groups of four to six. In these groups, the participants shared and commented on each other's essays online, using Google Docs. The small group discussions were aimed at supporting the coconstruction and sharing of knowledge (Scardamalia and Bereiter 2006) as well as developing a shared understanding of concepts (Lipponen 2002). The goal was to enhance conceptual development and change (e.g., Chi 2009; Vosniadou 2013; Chi and Wylie 2014), that is, to help participants build their teaching expertise through becoming familiar with educational concepts and discussing them. The groups were selected such that different levels of teaching experience (experienced teachers and novice doctoral students) and different faculties were represented in each group. In this way, the more experienced group members could share their experiences with the novices and the novices could ask advice from those with more experience. Furthermore, they could share feelings and solve problems collaboratively.

The three modules available in UNIPS at the time of this research were titled Becoming a Teacher, How to Plan My Teaching, and Lecturing and Expertise. The first module concerned the participants' development as teachers. Participants were expected to reflect on this theme in their essay, using the three scientific articles that were provided as support. In the second module, the participants wrote an essay concerning planning a course using the provided materials, such as articles and a video lecture. The third module focused on lecturing and expertise, and the participants wrote a summary of the arguments presented in four short video lectures reflecting their own experiences. All the essays were designed such that doctoral students with no previous teaching experience could also perform the tasks (for example, in the second module they wrote a course plan for an imaginary course). All three modules shared some general content, the most germane to the present research being the shift from a content-focused to a learning-focused approach in teaching. Other common contents were constructive alignment, the development of pedagogical expertise and teacher wellbeing. After writing the essays, the participants were divided into small groups, in which they commented on each other's texts and ideas. Each module was fully organised online; the role of the teacher was to read the essays and organise the group work phase. During this phase, the teacher monitored the discussion to keep the participants on track. After each module, the teacher gave brief, personal written feedback to the participants concerning their essay and participation in the group work phase.

\section{Using video clips with written interpretations as a method for studying conceptions of teaching}

Self-report Likert scale questionnaires have traditionally been a very popular method to study teacher knowledge and conceptions; they are sometimes complemented by interviews (Gow and Kember 1993; Kersting 2008; Prosser et al. 1994). This methodology has been dominant among many topics in psychological and educational research, such as motivation, where the current research is overly reliant on self-report measures (Fulmer and Frijters 2009). There are problems with both the idea of self-reporting and the Likert scale or other multiple-choice formats. Self-reporting relies on self-perception, which is prone to credibility issues such as motivation, memory, self-deception and faking problems (Paulhus 
and Vazire 2007). In self-reporting, it is assumed that people are aware of their mental processes and are able to remember them. It has been argued that self-reported measures are unsuitable for assessing unconscious processes or those which cannot be recalled (Harteis et al. 2018). Furthermore, self-reports include the risk of socially desirable responding, which refers to the tendency to present a favourable image of oneself. Respondents may believe the information they report (self-deception) or may provide responses that conform to socially acceptable values to avoid criticism or gain social approval (Fischer and Fick 1993; King and Bruner 2000). Multiple choice or Likert formats may also cause many issues, such as validity problems if the respondents do not understand the questions or terminology used (Fulmer and Frijters 2009).

Although self-reporting can be valid and informative in some cases, a broader selection of methods is called for. We claim that in studying teachers' conceptions, the use of selfreport Likert scale questionnaires leads to many risks. The most severe of these are the risk of self-perception problems with a questionnaire where the teachers cannot reliably report their beliefs and the risk of measuring problems on a questionnaire where the respondents do not understand what is meant by the questionnaire items. Thus, we claim that a method where a researcher analyses a respondent's interpretation of a situation can provide a more reliable view of the respondent's conceptions than just relying on self-reporting. In this study, we used a video-based approach to measure teachers' interpretations of teaching-learning situations.

The use of video-based assessments has recently become popular in research on teacher training (e.g., König et al. 2014; Blomberg et al. 2011). The benefits of this kind of assessment are that it resembles the complex reality of pedagogical situations (König et al. 2014) and that it is regarded as authentic by the participants (Dunekacke et al. 2015), thereby resulting in high user acceptance (Blomberg et al. 2011; see also Chan et al. 2010). In a study by Yadav and Koehler (2007), preservice teachers' views about the nature of knowledge and learning affected what they observed about teaching and learning from video cases. Furthermore, the participants' previously held epistemological beliefs were predictive of the statements in their written responses to the videos, with the result that similar situations were often written about in very different ways depending on the beliefs of the participants. Also, in a study by Calderhead and Robson (1991), student teachers' conceptions of teaching and professional development influenced what they found relevant and useful in the course and how they analysed their own and others' practice. In the same sense, we believe teachers' interpretations of typical teaching-learning situations can mirror their ideas and conceptions of teaching.

To study teachers' conceptions of teaching, we selected video assessments to avoid problems related to self-report measures, such as Likert scale questionnaires and interviews, and to increase respondents' motivation to take part in the research through authentic pedagogical situations. Analysing the participants' interpretations of the videos provided an indirect method of detecting their conceptions of teaching, which might often be unconscious and difficult to describe. Furthermore, the risk of providing socially desirable responses decreased through focusing on the interpretations of the videos instead of direct descriptions of one's own conceptions.

\section{Measurement instruments, materials and procedure}

The goal of ensuring the research equipment was compatible with studying in the UNIPS environment set certain boundaries for the data collection. For example, using a 
paper-and-pencil technique would have been difficult to implement and not in line with the entirely digital nature of the UNIPS environment; thus, an electronic tool was selected. We chose to embed the video clips in an electronic Webropol questionnaire with instructions for respondents to give their interpretations of the videos in written format online. Background questions were included in the same electronic questionnaire.

The two custom videos used actors as teachers and students, and represented typical university teaching-learning situations (see Unipeda Support 2017a, b). The videos were short: the first was $41 \mathrm{~s}$ in duration, and the second was $60 \mathrm{~s}$. A pedagogically interesting situation, a so-called trigger event, was incorporated in both videos. The videos were scripted, so that the targeted constructs could be clearly focused (König et al. 2014). The trigger events were designed to be domain-general, since the participants represented various disciplines. Furthermore, they aimed to represent realistic situations, since the perceived authenticity of the video material was regarded as highly important (Seidel et al. 2011). Both videos depicted a lecture situation in which a teacher is interrupted by a question from a student, but the teacher reacts differently between the two videos. The teacher's reaction to the student's question acts as a trigger in both videos. In the first video, the teacher is lecturing about cellular respiration and is interrupted by a question from the class concerning photosynthesis. As the teacher seems to think the question is important, she suggests the students take a moment to think about that together and asks the class how they would start solving the problem. Thus, the teacher activates the whole student group to discuss a tricky question raised by one of the students. In the second video, the teacher is giving a lecture on photosynthesis, and again, a student asks a question. The question is about the effect of climate change on photosynthesis. The teacher sidesteps the question by stating she was asked to talk solely about the chemical process; since the question is off topic, it will not be addressed. Thus, the teacher ignores the student's question since it did not directly relate to her original lecture plan. The teacher grows a bit confused after the interruption, saying, 'Where was I?' The first video was aimed to represent a learning-focused approach to teaching: to support the students' understanding and motivation, the teacher wants all the students to think about how two phenomena are connected. The second video was aimed to represent a content-focused approach to teaching because the teacher does not want to deviate from her current topic even though the question was related to the topic on a broader scale. In the same sense as drivers need to observe, interpret and react to meaningful situations in traffic (Carney et al. 2010), we expected these built-in pedagogical events to trigger certain reactions in teachers, depending on their beliefs about good teaching.

The study procedure is depicted in Table 2. Before beginning the university pedagogy course(s), respondents were sent the pre-test in the form of an online questionnaire via Webropol. The pre-test comprised background information questions and the video tasks. The prompt concerning the videos was: 'How would you interpret this teaching-learning situation? Briefly explain the idea, and if you are able to, use pedagogical concepts'. The participants were given a one-week timeframe to complete the questionnaire before they began the course. The three courses, bearing one ECTS credit each, ran simultaneously; each lasted five weeks. Immediately upon completing each course, the participants took the post-test by completing the same tasks concerning the videos. Answering the questionnaire both at the beginning and at the end of the course was included in the course tasks; however, the respondents could choose whether they wanted to allow their responses to be used as data for the research. 


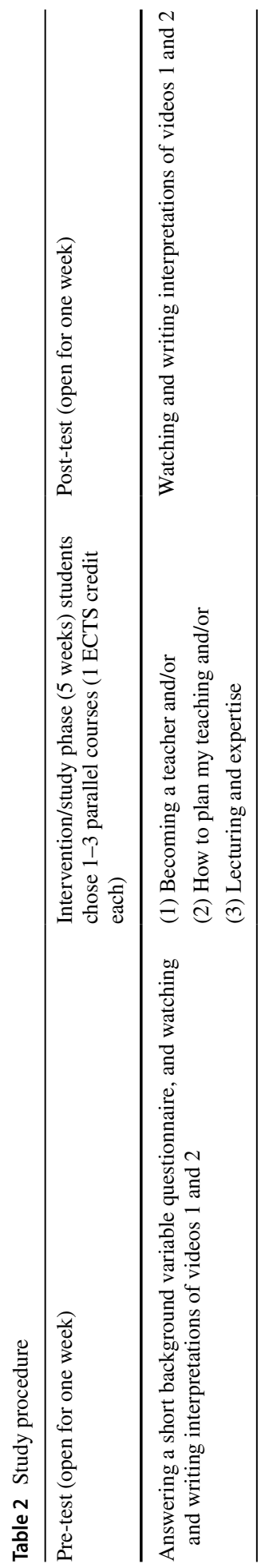




\section{Data analysis}

In the present study, the teachers' interpretations of the video clips, which represent the content- and learning-focused approaches to teaching, respectively, were analysed. These interpretations, which reveal how the teachers understand teaching-learning situations, were seen to mirror their conceptions of teaching. The first and fourth authors analysed the answers to the open-ended questions about the video interpretations. The length of the written answers was approximately 60 words in the first measurement and 50 words in the second measurement. In some cases, the entire answer focused on the trigger while in others, the text focusing on the trigger was either shorter than their entire answer or, in a few cases, absent.

The analysis was conducted using a theory-driven approach (Elo and Kyngäs 2008; Hsieh and Shannon 2005), in which analysis codes were derived from theory before and during data analysis. The features of either a knowledge-transmission conception or a learningfacilitation conception of teaching were sought (see Kember and Kwan 2000; Samuelowicz and Bain 2001). The researchers negotiated the features, and certain classifications were decided. Although the theoretical categories were decided before the analysis, the number of categories was not set. From the first reading, several tentative categories were formed by both researchers. The categories were tested by analysing the data with them. The categories were then further developed, resulting in a four-category model, the focus of teaching being on: (a) delivering content, (b) performing, (c) supporting learning, and (d) helping students to feel comfortable in learning situations. This categorisation was promising; however, categories $b$ and $d$ had only a few observations, so that would not work for further analyses.

The final analysis was based on classifying the interpretation of the trigger (positive or negative reaction towards the trigger) as the knowledge-transmission conception, the learning-facilitation conception or as an unclear conception of teaching. One answer could only contain one unit of analysis. We acknowledge that many respondents hold conceptions that include elements from both categories and that the dichotomisation of the teaching conceptions into either knowledge transmission or learning facilitation simplifies the richness of the conceptions; however, to enable testing the change in teachers' interpretations during the training, this solution was considered to be the best.

A scoring rubric (Table 3 ) about descriptions of teaching conceptions was developed to guide the analysis. For example, if the respondent expressed that a possible question from

Table 3 Descriptions of conceptions of teaching

\begin{tabular}{lc}
\hline Conception of teaching & Description of the conception \\
\hline Teaching as knowledge transmission & $\begin{array}{c}\text { Delivering information from } \\
\text { teacher to students, focusing } \\
\text { on individual learning prac- } \\
\text { tices, sticking with the planned } \\
\text { timetable in teaching, knowing }\end{array}$ \\
all answers to students' ques- \\
tions, going through all planned \\
materials \\
Encouraging students' own think- \\
ing, aiming at conceptual change, \\
fostering collaborative knowl- \\
edge creation in interaction with \\
teacher and among students, sup- \\
porting self-regulated individual- \\
and group-level learning
\end{tabular}


a student should be postponed to the end of the lecture, that answer would be classified as a knowledge-transmission conception. Similarly, if a respondent thought it was a problem if a teacher did not know the answer to a student's question, it was classified as knowledge transmission. There were also some unclear answers that did not fit into either of the categories (video 1: pre-test $8 \%$, post-test $3 \%$; video 2: pre-test $15 \%$, post-test $11 \%$ ). Those answers, for example, stated merely what had happened in the clip without taking a stand on whether the teacher had acted appropriately. One example of an unclear conception from the first video in the pre-test was 'dialogue, questions' (P39), and another from the second video in the pre-test was 'The student asks a question that is not related to the topic according to the teacher. The teacher listens but ignores answering the question appealing to some higher authority by saying she is meant to focus only on certain things' (P68).

The classification principles are explained in more detail in "Interpretations of the first video: Teacher adopting the learning-focused approach to teaching" and "Interpretations of the second video: Teacher adopting the content-focused approach to teaching" sections. After creating the categories and classification principles, the researchers coded all answers individually in these three categories. The interrater reliability was found to be $87 \%$ for the first video and $80 \%$ for the second video. The raters reached consensus by discussing the answers they had classified inconsistently. After this, the unclear conceptions were removed from further analyses.

As the interpretations were classified into two categories resulting in a dichotomous variable, the changes in the interpretations from the pre-test to the post-test were examined with non-parametric McNemar tests. Chi square tests were used to analyse the differences between groups formed by various background variables (faculty, status, previous pedagogical education and amount of teaching experience). The changes in conceptions from the pre-test to the post-test within these groups were examined with McNemar tests using the split-file condition.

\section{Results}

\section{Teachers' conceptions of the teaching-learning situations}

\section{Interpretations of the first video: Teacher adopting the learning-focused approach to teaching}

Participants whose interpretation of the first video was classified as representing a knowledge-transmission conception of teaching were mainly worried about losing the structure of the lecture and that the discussion surrounding the question would take too much valuable lecture time. They suggested that discussions should be postponed until the end of the lecture:

The teacher changed the subject when the question emerged and proposed a new question to the class. In general, it is good to take into account the questions and comments from the class, but maybe this could have been explained later as now the structure was lost. (P48, university teacher, pre-test)

The question of the student interrupting the lecture and spending time to think about the question is not good because the rest of the students are not ready to think and the sequence of the lecture will be disturbed. So the questions should be postponed to the end of the lecture to avoid wasting lecture time. (P11, doctoral student with teaching duties, pre-test) 
The teacher let a too-early and complicated question interrupt the lecture. Such discussion should be left to the end of the lecture. (P70, University teacher, pre-test)

Furthermore, participants with knowledge-transmission interpretations suggested that the teacher should have answered the question immediately to address the question quickly or should have just stated that the question was off topic and would not be addressed during the lecture. One participant also questioned the discussion between students in a situation where the question was targeted to the teacher - that it would be the teacher's responsibility to answer. We interpreted that as representing a knowledge-transmission conception of teaching.

She does not answer the question the student asked. Instead, she avoids answering by asking more questions. She could directly explain first and ask other questions in other ways because this was the beginning of the class, and there are other tasks to do rather than being side-tracked all of a sudden because of a question from a student. (P67, doctoral student without teaching duties, pre-test)

The student's question was from a different field. The teacher could have answered that this course is addressing... and will not focus on ... (P17, university teacher, pre-test)

I would say this is not a problem for the students to answer. The teacher was asked a straight question. (P62, university teacher, pre-test)

Participants whose interpretation of the first video clip was learning facilitation emphasised the importance of interaction and the active role of the students in answering the question:

Good teaching. Interaction with students so they could understand the topic and learn through the discussion. (P2, doctoral student without teaching duties, pre-test) Perfect! The teacher (is not afraid and) allows the student to ask a question. Then the teacher addresses the subject asked and throws the question back to the students so that they (students and teacher) together will figure out how to solve the question. (P41, doctoral student with teaching duties, pre-test)

Additionally, participants with learning facilitation answers highlighted the role of previous knowledge in learning, constructing new knowledge on top of existing knowledge structures and combining knowledge from different sources:

In this teaching situation, the new knowledge is compared with the old knowledge. The teacher also encourages the students to think for themselves. (P1, doctoral student without teaching duties, pre-test)

Although the instructor in this clip does not start with connecting the topic of the lecture with contents in other courses, a student does this himself (which is great, as it means the student isn't treating the courses as separate elements but rather wants to know how the various bits of information fit together). The instructor does not immediately answer the question but rather lets the class discuss it together. (P44, doctoral student without teaching duties, pre-test) 
Eight participants changed their interpretation from knowledge transmission to a learning facilitation view of teaching after participating in university pedagogy course(s). In the following example, a participant first thought that the question should have been addressed later. However, in the post-test answer, the participant saw the situation in a different light, highlighting the students' activation and engagement:

The teacher attempts to interact with the students, which is good. However, it seems that the lecture has just started, and she has not even begun to explain the subject of respiration. So she could probably have postponed answering the question to a later time and then asked the same student how he would answer it then. Instead, she is confronting the students with too many questions without enough information to get going. (P13, university teacher, pre-test)

With regard to what I have learned in this course, I have to put my previous answer to this question into perspective (if I remember it correctly). I think that the teacher's reaction is very good in that she uses the opportunity to activate the class by referring the question to the students. She does not, however, just ask the same question but instead creates a problem and asks how the students would go about solving it. By that, she acknowledges that she does not know everything (even though she probably knows the answer) and leaves room for discussion, motivating the class to find an answer that is not predetermined. At the same time, the students are encouraged to engage in the subject, whether they find it very interesting or not. In other words, she applies a clearly student-focused and learning-centred approach to teaching. (P13, university teacher, post-test)

In another example, a participant first saw the teacher's reaction as a professional way of handling a tricky question by turning it into a teaching method. However, there was no mention of that in the post-test answer; rather, it focused on engaging students in discussions and detecting students' previous knowledge and interests. Thus, the viewpoint of the interpretation changed from the teacher's action to the students' learning:

The lecturer is not scared by the aggressive-style question but handles the situation professionally, turning it into a teaching 'method'. (P26, university teacher, pre-test) The student poses a question about the course topic, and the teacher uses this as an opportunity to engage in further discussion with the students. This allows the teacher to learn about the knowledge level and interests of the students and tie the course topic into the bigger entity and other study subjects. (P26, university teacher, posttest)

\section{Interpretations of the second video: Teacher adopting the content-focused approach to teaching}

Participants' answers to questions about the second video were also classified as representing either a learning-facilitation or a knowledge-transmission view of teaching. Participants with interpretations reflecting knowledge transmission agreed it was good that the teacher allowed a student to ask a question, but at the same time, it was appropriate to ignore the question to avoid deviating from the subject.

A student asks a question, but it is off the topic. The teacher stays nicely on topic. (P28, doctoral student with teaching duties, pre-test) 
This teaching and learning situation is fine for the following reasons: 1 . The teacher let the student ask the question during the lecture. 2. However, she limited herself to the topic at hand. (P23, doctoral student with teaching duties, pre-test)

The teacher could have explained that this lecture focuses on theoretical grounds and later lectures address the questions asked by the student. (P17, University teacher, pre-test)

For the participants with learning-facilitation interpretations, it would have been important to receive an answer the question, either by the teacher or the group, or at least inform the student when the matter would be addressed or where the student could get more information:

This is the completely wrong way to answer that question. The point is not just to make the students learn a process through just textbooks but make them think more creatively. The student asked a very relevant question which affects us very much now. If I did not know the answer, I would have told them that it was a very nice question, and I currently don't have a complete answer for you, but I will come back to you in the next lecture. (P43, doctoral student without teaching duties, pre-test)

The teacher starts well, but after a while, she speaks and lectures only for herself, without contact with the class. When a student asks a question, the teacher could take advantage of the situation and redesign the content of the lesson and follow the students' interest. If it is not possible to discuss this topic in the situation, it would be good to point out when the matter will be addressed or where the student can find more information on the subject. The teacher could take advantage of the interaction in the classroom and questions asked by students. That's a way to activate students and help them to build up their agency. (P22, doctoral student without teaching duties, pre-test)

After participating in university pedagogy courses, a total of 14 respondents changed their interpretations concerning the second video. In the following example, the participant first thought that the teacher should have paid more attention to the content of the lecture. After the intervention, the participant saw a safe atmosphere in which to ask questions as more important. Thus, the focus of the answer changed from transmission of knowledge to facilitating students' learning.

In the video, even though the teacher has the specific topic for the day, I believe the student's question is very much related to the topic. The teacher should have started the topic by giving an illustration of how plants and animals exchange carbon dioxide and oxygen and relate it to global warming. (P50, doctoral student with teaching duties, pre-test)

The teachers' role is to create an atmosphere wherein the students feel safe to question, challenge each other and the teachers, and reflect on their own learning process. The teachers should also create activities that lead the students to ponder their prior knowledge. Thus, the teachers' role in a constructivist class is not so much to lecture but to act as an expert who can accelerate knowledge formation. The role of the teacher in a constructivist class is also to assist students in developing new insights. The activities are student-centred, and students are encouraged to ask their own questions, carry out their own experiments, make their own analogies, and come to their own conclusions. However, this teacher makes the students feel uncomfortable asking questions, and this will make the teacher the only speaker. (P50, doctoral student with teaching duties, post-test) 
Table 4 Participants' interpretations of the first video before and after the intervention

Table 5 Participants' interpretations of the second video before and after the intervention

\begin{tabular}{llrll}
\hline $\begin{array}{l}\text { Interpretation of } \\
\text { video } 1\end{array}$ & Post & & $n$ & $p$ value \\
\cline { 2 - 3 } & KT $n(\%)$ & LF $n(\%)$ & & \\
\hline Pre & & & & \\
KT & $9(19)$ & $8(17)$ & 48 & $.008^{\mathrm{a}}$ \\
LF & $0(0)$ & $31(65)$ & & \\
\hline
\end{tabular}

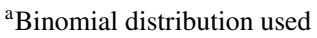

$* p<.05, * * p<.01, * * * p<.001$

$K T$ knowledge transmission interpretation of teaching, $L F$ learning facilitation interpretation of teaching

\begin{tabular}{|c|c|c|c|c|}
\hline \multirow{2}{*}{$\begin{array}{l}\text { Interpretation of } \\
\text { video } 2\end{array}$} & \multicolumn{2}{|l|}{ Post } & \multirow[t]{2}{*}{$n$} & \multirow[t]{2}{*}{$p$ value } \\
\hline & $\mathrm{KT} n(\%)$ & $\operatorname{LF} n(\%)$ & & \\
\hline \multicolumn{5}{|l|}{ Pre } \\
\hline KT & $13(32)$ & $14(34)$ & 41 & $.000^{\mathrm{a}}$ \\
\hline LF & $0(0)$ & $14(34)$ & & \\
\hline
\end{tabular}

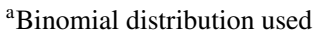

$* p<.05, * * p<.01, * * * p<.001$

$K T$ knowledge transmission interpretation of teaching, $L F$ learning facilitation interpretation of teaching

Another participant first thought that the teacher should not have interrupted her teaching in the first place because she grew confused. In the post-test answer, the participant thought the situation could have been used to support learning:

The teacher is interrupting the teaching in the middle of the sentence when a student has a question. It can sometimes be OK; it depends on the situation. But in this case, it was so in the middle that the teacher gets confused and doesn't even answer the question. The student can feel stupid or ashamed or disturbed and maybe doesn't ask questions anymore. (P55, doctoral student with teaching duties, pre-test)

Even if this topic is not part of the lecture content, the situation could be used to support the learning. Perhaps the question came to the student because his former knowledge structure is activated and he remembers that these topics are connected. He aims to clarify the structure so that it would be then easier to continue to process the information. So, the teacher could give a short, even quite general answer which then helps the student, and the teacher could say that there will be more about this topic coming later. But not leave the student unclear. (P55, doctoral student with teaching duties, post-test)

\section{Overall change in interpretations before and after the short online course(s)}

From the pre-test to the post-test, eight participants changed their interpretation from knowledge transmission to learning facilitation for the first video; according to the 
McNemar's test, there was a statistically significant difference in the proportion of learning facilitation conceptions pre- and post-intervention $(p=.008)$ (see Table 4). In the second video with the content-focused teacher, 14 respondents changed their interpretation from a knowledge-transmission to a learning-facilitation view after participating in the university pedagogy courses (McNemar's test, $p=.000$; see Table 5). Thus, from the pre-test to the post-test, the participants' interpretations of the videos changed statistically significantly toward the learning facilitation view.

Since not all participants took part in all three offered courses, we studied the change in interpretations within each course separately. To do this, we split the data in half into those who participated in the courses and those who did not (see Tables $10,11 \& 12$ in Appendix). In the Becoming a Teacher course, a statistically significant difference in interpretations was found between the pre- and post-tests using McNemar's tests for both videos among respondents who took part in the course (video 1: $p=.016$; video 2: $p=.004$ ); this finding indicates that the course succeeded in changing the participants' interpretations. The same happened among the respondents who participated in the How to Plan My Teaching course (video 1: $p=.031$; video 2: $p=.000$ ) and the Lecturing and Expertise course (video $1: p=.016$; video $2: p=.000$ ). We continued testing this hypothesis by comparing the total number of courses taken. According to the results, completing all three courses had the strongest effect (see Tables 6 and 7). This means that taking one UNIPS course had some effect, but the best effect was obtained by a combination of the three courses.

\section{Underlying factors connected to the change in the interpretations}

Before the changes within different groups were examined, comparisons were made between the groups in the pre-test to see whether there were any statistically significant

Table 6 Participants' interpretations of the first video (pre and post) related to the number of courses studied

\begin{tabular}{|c|c|c|c|c|c|}
\hline \multirow[t]{3}{*}{ Total number of courses taken } & \multicolumn{3}{|c|}{ Interpretation of video 1} & \multirow[t]{3}{*}{$n$} & \multirow[t]{3}{*}{$p$ value $^{\mathrm{a}}$} \\
\hline & & \multicolumn{2}{|l|}{ Post } & & \\
\hline & & $\mathrm{KT} n(\%)$ & LF $n(\%)$ & & \\
\hline \multirow[t]{3}{*}{ One course (1 ECTS credit) } & Pre & & & & \\
\hline & KT & $3(20)$ & $2(13)$ & 15 & .500 \\
\hline & LF & $0(0)$ & $10(67)$ & & \\
\hline \multirow[t]{3}{*}{ Two courses (2 ECTS credits) } & Pre & & & & \\
\hline & KT & $1(9)$ & $0(0)$ & 11 & 1.000 \\
\hline & $\mathrm{LF}$ & $0(0)$ & $10(91)$ & & \\
\hline \multirow[t]{3}{*}{ Three courses ( 3 ECTS credits) } & Pre & & & & \\
\hline & KT & $5(23)$ & $6(27)$ & 22 & $.031^{*}$ \\
\hline & $\mathrm{LF}$ & 0() & $11(50)$ & & \\
\hline
\end{tabular}

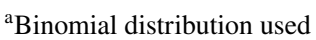

$* p<.05, * * p<.01, * * * p<.001$

$K T$ knowledge transmission interpretation of teaching, $L F$ learning facilitation interpretation of teaching 
Table 7 Participants' interpretations of the second video (pre- and post) related to the number of courses studied

\begin{tabular}{|c|c|c|c|c|c|}
\hline \multirow[t]{3}{*}{ Total number of courses taken } & \multicolumn{3}{|c|}{ Interpretation of video 2} & \multirow[t]{3}{*}{$n$} & \multirow[t]{3}{*}{$p$ value } \\
\hline & & \multicolumn{2}{|l|}{ Post } & & \\
\hline & & $\mathrm{KT} n(\%)$ & $\mathrm{LF} n(\%)$ & & \\
\hline \multirow[t]{3}{*}{ One course (1 ECTS credit) } & Pre & & & & \\
\hline & KT & $5(45)$ & $3(27)$ & 11 & .250 \\
\hline & LF & $0(0)$ & $3(27)$ & & \\
\hline \multirow[t]{3}{*}{ Two courses (2 ECTS credits) } & Pre & & & & \\
\hline & KT & $2(20)$ & $3(30)$ & 10 & .250 \\
\hline & LF & $0(0)$ & $5(50)$ & & \\
\hline \multirow[t]{3}{*}{ Three courses (3 ECTS credits) } & Pre & & & & \\
\hline & KT & $6(30)$ & $8(40)$ & 20 & $.008 * *$ \\
\hline & LF & 0() & $6(30)$ & & \\
\hline
\end{tabular}

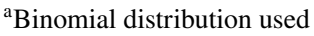

$* p<.05, * * p<.01, * * * p<.001$

$K T$ knowledge transmission interpretation of teaching, $L F$ learning facilitation interpretation of teaching

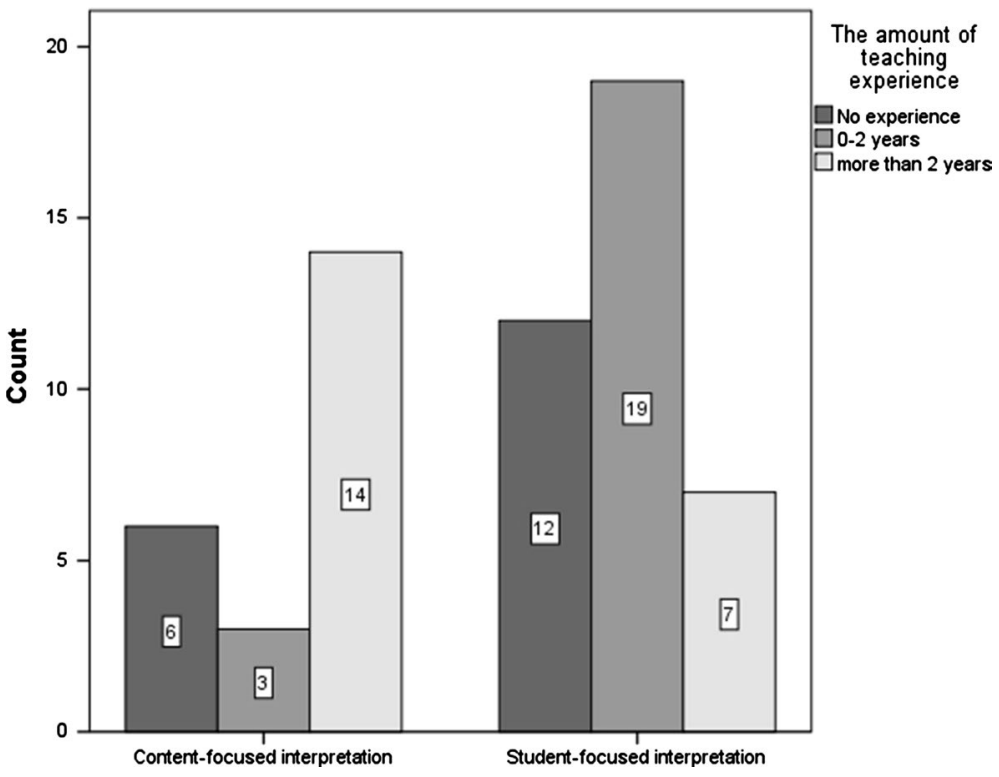

Fig. 1 The participants' interpretations of the first video in the pre-test

differences in the baseline. Chi square tests revealed no statistically significant differences concerning the faculty, status (university teacher vs. doctoral student) or previous pedagogical education. However, when teaching experience was compared between the groups, a difference was found for the first video $\left(x^{2}(2)=13.07, p<.01\right.$, Cramer's $\left.\mathrm{V}=.46\right)$. Thus, the 
amount of teaching experience seems to be connected to how the participants interpreted the first video in the pre-test (Fig. 1). It seems that those with more than two years of teaching experience represented more knowledge transmission in their interpretations, whereas those with less experience tended to interpret the situation more often in terms of learning facilitation.

Table 8 Participants' interpretations of the first video in relation to the background variables

\begin{tabular}{|c|c|c|c|c|c|c|}
\hline \multicolumn{2}{|c|}{ Background variable } & \multicolumn{3}{|c|}{ Interpretation of video 1} & \multirow[t]{3}{*}{$n$} & \multirow[t]{3}{*}{$p$ value $^{\mathrm{a}}$} \\
\hline & & & \multicolumn{2}{|l|}{ Post } & & \\
\hline & & & $\mathrm{KT} n(\%)$ & LF $n(\%)$ & & \\
\hline \multirow[t]{6}{*}{ Faculty } & Social sciences and humanities & Pre & & & & \\
\hline & & KT & $5(31)$ & $1(6)$ & 16 & 1.000 \\
\hline & & LF & $0(0)$ & $10(63)$ & & \\
\hline & Natural sciences, law, and economy & Pre & & & & \\
\hline & & KT & $4(13)$ & $7(23)$ & 31 & $.016^{*}$ \\
\hline & & LF & $0(0)$ & $20(65)$ & & \\
\hline \multirow[t]{9}{*}{ Status } & University teacher & Pre & & & & \\
\hline & & KT & $5(36)$ & $3(21)$ & 14 & .250 \\
\hline & & $\mathrm{LF}$ & $0(0)$ & $6(43)$ & & \\
\hline & Doctoral student with teaching duties & Pre & & & & \\
\hline & & KT & $1(6)$ & $3(19)$ & 16 & .250 \\
\hline & & $\mathrm{LF}$ & $0(0)$ & $12(75)$ & & \\
\hline & Doctoral student without teaching duties & Pre & & & & \\
\hline & & KT & $3(17)$ & $2(11)$ & 18 & .250 \\
\hline & & LF & $0(0)$ & $13(72)$ & & \\
\hline \multirow{6}{*}{$\begin{array}{l}\text { Previous } \\
\text { (university) } \\
\text { pedagogical } \\
\text { education }\end{array}$} & No & Pre & & & & \\
\hline & & KT & $7(22)$ & $6(19)$ & 32 & $.031^{*}$ \\
\hline & & LF & $0(0)$ & $19(59)$ & & \\
\hline & Yes & Pre & & & & \\
\hline & & KT & $2(13)$ & $2(13)$ & 16 & .500 \\
\hline & & $\mathrm{LF}$ & $0(0)$ & $12(75)$ & & \\
\hline \multirow{9}{*}{$\begin{array}{l}\text { Amount of } \\
\text { teaching } \\
\text { experience }\end{array}$} & No experience & Pre & & & & \\
\hline & & KT & $1(7)$ & $3(21)$ & 14 & .250 \\
\hline & & $\mathrm{LF}$ & $0(0)$ & $10(71)$ & & \\
\hline & Up to 2 years & Pre & & & & \\
\hline & & KT & $2(11)$ & $1(6)$ & 18 & 1.000 \\
\hline & & LF & $0(0)$ & $15(83)$ & & \\
\hline & More than 2 years & Pre & & & & \\
\hline & & KT & $6(38)$ & $4(25)$ & 16 & .125 \\
\hline & & $\mathrm{LF}$ & $0(0)$ & $6(38)$ & & \\
\hline
\end{tabular}

${ }^{\mathrm{a}}$ Binomial distribution used

$* p<.05, * * p<.01, * * * p<.001$

$K T$ knowledge transmission interpretation of teaching, $L F$ learning facilitation interpretation of teaching 
Table 9 Participants' interpretations of the second video in relation to the background variables

\begin{tabular}{|c|c|c|c|c|c|c|}
\hline \multicolumn{2}{|c|}{ Background variable } & \multicolumn{3}{|c|}{ Interpretation of video 2} & \multirow[t]{3}{*}{$n$} & \multirow[t]{3}{*}{$p$ value } \\
\hline & & & \multicolumn{2}{|l|}{ Post } & & \\
\hline & & & $\operatorname{IT} n(\%)$ & LE $n(\%)$ & & \\
\hline \multirow[t]{6}{*}{ Faculty } & \multirow[t]{3}{*}{ Social sciences and humanities } & Pre & & & & \\
\hline & & $\mathrm{KT}$ & $3(20)$ & $4(27)$ & 15 & .125 \\
\hline & & LF & $0(0)$ & $8(53)$ & & \\
\hline & \multirow[t]{3}{*}{ Natural sciences, law, and economics } & Pre & & & & \\
\hline & & KT & $10(38)$ & $10(38)$ & 26 & $.002 * *$ \\
\hline & & LF & $0(0)$ & $6(23)$ & & \\
\hline \multirow[t]{9}{*}{ Status } & \multirow[t]{3}{*}{ University teacher } & Pre & & & & \\
\hline & & KT & $4(33)$ & $3(25)$ & 12 & .250 \\
\hline & & LF & $0(0)$ & $5(42)$ & & \\
\hline & \multirow[t]{3}{*}{ Doctoral student with teaching duties } & Pre & & & & \\
\hline & & KT & $6(40)$ & $6(40)$ & 15 & $.031 *$ \\
\hline & & LF & $0(0)$ & $3(20)$ & & \\
\hline & \multirow[t]{3}{*}{ Doctoral student without teaching duties } & Pre & & & & \\
\hline & & KT & $3(21)$ & $5(36)$ & 14 & .063 \\
\hline & & LF & $0(0)$ & $6(43)$ & & \\
\hline \multirow{6}{*}{$\begin{array}{l}\text { Previous } \\
\text { (university) } \\
\text { pedagogical } \\
\text { education }\end{array}$} & \multirow[t]{3}{*}{ No } & Pre & & & & \\
\hline & & KT & $8(29)$ & $10(36)$ & 28 & $.002 * *$ \\
\hline & & LF & $0(0)$ & $10(36)$ & & \\
\hline & \multirow[t]{3}{*}{ Yes } & Pre & & & & \\
\hline & & KT & $5(38)$ & $4(31)$ & 13 & .125 \\
\hline & & LF & $0(0)$ & $4(31)$ & & \\
\hline \multirow{9}{*}{$\begin{array}{l}\text { Amount of } \\
\text { teaching } \\
\text { experience }\end{array}$} & \multirow[t]{3}{*}{ No experience } & Pre & & & & \\
\hline & & $\mathrm{KT}$ & $3(23)$ & $5(38)$ & 13 & .063 \\
\hline & & LF & $0(0)$ & $5(38)$ & & \\
\hline & \multirow[t]{3}{*}{ Up to 2 years } & Pre & & & & \\
\hline & & KT & $1(8)$ & $6(46)$ & 13 & $.031 *$ \\
\hline & & LF & $0(0)$ & $6(46)$ & & \\
\hline & \multirow[t]{3}{*}{ More than 2 years } & Pre & & & & \\
\hline & & KT & $9(60)$ & $3(20)$ & 15 & .250 \\
\hline & & LF & $0(0)$ & $3(20)$ & & \\
\hline
\end{tabular}

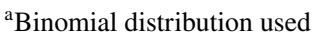

$* p<.05, * * p<.01, * * * p<.001$

$K T$ knowledge transmission interpretation of teaching, $L F$ learning facilitation interpretation of teaching

The changes in interpretation were examined against the background variables used in the study, that is, faculty, status of the participant, previous pedagogical education and teaching experience (see Tables 8 and 9). Within the different background variable groups, several statistically significant differences were found between the pre-test and the posttest. According to McNemar's tests, the differences between the pre-test and the post-test were statistically significant among the participants from the natural sciences, law, and economics faculties, meaning that teachers and doctoral students from these faculties changed 
their interpretation from knowledge transmission to learning facilitation. In addition, those participants who had no previous pedagogical education changed their interpretations from knowledge transmission to learning facilitation from the pre-test to the post-test. For the second video, the difference between the pre- and post-tests was statistically significant among the doctoral students who had teaching duties. It was almost statistically significant within the group of doctoral students with no teaching duties and among the novice teachers who had from zero to two years of teaching experience. Thus, it seems that studying in the UNIPS modules helped relatively inexperienced teachers to change their interpretations from a knowledge-transmission view to a learning-facilitation view.

\section{Discussion}

The aim of this study was to explore whether short online pedagogy courses can have an effect on university teachers' conceptions of the teaching-learning phenomenon. The respondents were asked to interpret short video clips of teaching situations, representing learning- and content-focused approaches to teaching, before and after they had participated in online pedagogy courses. These interpretations were seen to reflect the participants' conceptions of teaching (cf. Calderhead and Robson 1991; Van Rossum et al. 1985). Furthermore, we investigated which background variables were connected to the changes in the interpretations.

The results showed that university teachers' interpretations of the teaching situations leaned toward a learning-facilitation interpretation after they completed the online pedagogy course(s). This result was found for both videos used in the study. Furthermore, in each of the three pedagogy courses, the change was statistically significant among those who had participated in the course. These results are in line with previous studies that identified a shift in thinking towards a student-centric view after participation in pedagogical training (Gibbs and Coffey 2004; Hanbury et al. 2008; Light and Calkins 2008; Stewart 2014), although in those studies the training lasted one year and the methodology was different. In the present study, the shift happened much faster, after a short, five-week intervention. Thus, previous research suggested that longer periods of pedagogical training are needed (Gibbs and Coffey 2004; Postareff et al. 2007; Prebble et al. 2004), while our study indicated that shorter training programmes might also result in changes in interpretation. We argued that these interpretations reflect the participants' conception of teaching (cf. Calderhead and Robson 1991; Van Rossum et al. 1985). Postareff et al. (2008a, b) found that only after a longer period (one academic year, 30 ECTS credits) of training did teachers report being more learning-focused than before any training. The researchers suggested that shorter training programmes might even make teachers more uncertain about themselves as teachers as when they begin their pedagogical education they suddenly become aware of their limitations and feel more uncertain about their abilities as teachers. The teachers might also feel less student-focused than before. Contrary to the Postareff et al. (2008a, b) study, we did not use self-report measures but rather video interpretations that were evaluated by researchers. We argued that the interpretations of video clips as a method might reflect the change in conceptions more realistically than self-reported changes. It should be noted that many of the previous studies (e.g., Postareff et al. 2008a, b) also explored changes in teachers' approaches to teaching, that is, the teachers' intentions and teaching strategies, while the present study focused on teachers' conceptions.

The changes in interpretations were statistically significant among doctoral students, those with fewer than two years of teaching experience, those with no previous pedagogical 
education and participants from the natural sciences, law, and economics faculties. One of the main results of the study was that conceptions changed from the pre-test to the post-test among relatively new academics: doctoral students and those with fewer than two years of teaching experience. Changing conceptions among more experienced teachers may be more challenging, which is also supported by previous research (Ertmer 2005; Lueddeke 2003; Marsh 2007; Postareff and Nevgi 2015). For example, according to Lueddeke (2003), mid-career teachers have a conscious or unconscious desire to avoid change or a fear of choosing or making a commitment. We suggest that for more experienced academics and teachers, the boundaries between their own subject knowledge and pedagogical knowledge might act as obstacles to learning. University teachers are experts in their own disciplines, but when it comes to pedagogy, these teachers are more or less novices because most university teachers have only limited knowledge of pedagogical theories and educational sciences (Postareff and Nevgi 2015). Akkerman (2011) argued that explicitly identifying boundaries is a prerequisite for learning because this action creates a collective need to take an unfamiliar practice or perspective more thoroughly into account. It might be that a short online course does not help identify these boundaries and thus cannot support the changing of the conceptions of teaching of more experienced participants. Therefore, academic novices, such as doctoral students, who do not have such cultivated expertise in their own fields, might be more open to this new pedagogical knowledge. For them, the changes in teaching conceptions might be more easily realisable than for more experienced teachers, who already have established certain teaching methods, and whose conceptions of teaching may be more stabilised, forming a framework theory kind of structure that changes slowly (Vosniadou and Skopeliti 2014).

It can be concluded from these results that even a short intervention may have an effect on interpretations of teaching, especially when the participants are relatively new teachers, such as doctoral students. Furthermore, the change in interpretations happened among the participants from the faculties of the natural sciences, medicine, and law but not among the participants from the social sciences and humanities. Researchers have previously shown that disciplines are connected to teaching approaches in the sense that teachers in the natural sciences tend to be more content-focused and teachers in the social sciences and humanities more learning-focused (Lueddeke 2003; Trigwell 2002). Thus, for participants coming from traditionally content-focused disciplines, the pedagogy courses might have been more of an eye-opening experience. This could also explain the changes in interpretations among the participants with no previous pedagogical training.

Reviews of instructional development in higher education (Levinson-Rose and Menges 1981; Steinert et al. 2006; Stes et al. 2010; Weimer and Lenze 1998) have claimed more variability in methodology and approaches in researching the impact of development initiatives, thus not only drawing on the self-reports of the participants but also measuring actual behavioural outcomes. Although the present study did not measure actual changes in the participants' performance or approaches, this study went one step further from the traditional self-report questionnaires by examining the participants' interpretations of teaching-learning situations. We believe that the expressed interpretations reflect conceptions of teaching (cf. Van Rossum et al. 1985), and we think that the video-based method we used is complementary to traditional questionnaires (Kaiser et al. 2015) in the sense that it is not based on the participants' self-evaluation but rather on the evaluation made by researchers. This way, at least the common pitfalls of traditional self-report questionnaires, such as difficulty in detecting unconscious processes (Harteis et al. 2018) and risk of socially desirable responses (Fischer and Fick 1993; King and Brunner 2000), can be avoided. Furthermore, with the help of video-based instruments it is possible to capture the way 
teachers notice and interpret particular events and aspects of teaching-learning situations (Kaiser et al. 2015). We also think that the ecological validity of this type of measurement is rather high, since the videos resembled authentic situations. However, the video clips we used comprised only two short teaching-learning situations with only one pedagogically interesting trigger in each video. This structure might result in limited insight into university teaching and thereby the participants' ideas of good teaching. In our future studies, the number of videos or triggers should be increased in order to attain greater insight into teachers' conceptions. An additional strength of the study is the pre-test/post-test design, which enabled examining the possible effect of pedagogical education against a certain baseline. Since the prompt concerning the videos was open-ended and applied in nature, and was not iterative or based on memorising the specific contents of the courses, we argue that the post-test goes beyond measuring participants' ability to apply acquired knowledge.

The present study has additional limitations that should be taken into account. First, we identified only the participants' interpretations of the triggers in the videos, and classified them as representing either knowledge transmission, learning facilitation or an unclear conception of teaching. We are aware that the conceptions of teachers might in some cases include both knowledge transmission and learning enhancing elements, and categorising them as representing only one type of conception might not capture the richness of the conceptions. To enable measuring whether a change occurred in teachers' interpretations during a pedagogy course, classifying the reaction to the trigger into the three aforementioned categories was deemed the best solution because it allowed us to conduct the quantitative analyses. In our next study, we aim to conduct a more fine-grained analysis that captures the richness of the conceptions in more detail.

Another limitation is that we measured changes in expressed interpretations, which might have nothing to do with respondents' teaching performance. However, previous research has shown that conceptions are connected to approaches (Kember and Kwan 2000), so it is probable that interpretations are also related to teachers' approaches.

The pre-test/post-test design addressed the immediate changes in the participants' interpretations; however, without a delayed post-test, it was impossible to show the permanence of the change. In addition, our sample might be biased since the participants took the courses on a voluntary basis, that is, they might have developed their ideas of teaching even without the course. In further research, a control group of teachers who do not take part in a course could be included to see whether the changes are related to taking these particular courses or some other factors. If a control group were to be a sample of university teachers who do not attend any pedagogical training programmes, we assume they would not develop in the same manner and in the same timeframe as the teachers taking part in UNIPS training. A question also remains as to whether more traditional pedagogical training would reach similar results in the same timeframe. If this were the case, we can still infer that the short UNIPS trainings are also capable of creating changes in teachers' interpretations.

\section{Conclusion}

The study showed that short online pedagogical training programmes have the potential to affect participants' interpretations of teaching situations, especially when the participants are not very experienced in teaching. These changes might be a sign of preliminary changes in the teachers' underlying teaching conceptions. Thus, we argue that pedagogical 
training should be offered before recruitment to teaching tasks at the university, that is, as part of doctoral studies or at the beginning of a teaching career. Offering pedagogical training for new or future faculty could change the traditional convention of novice teachers performing their first teaching tasks without any pedagogical support. This would help to promote a pedagogical culture across departments and generate forms of continuous learning in pedagogical expertise.

Acknowledgements Open access funding provided by University of Turku (UTU) including Turku University Central Hospital. The authors wish to thank the Finnish Ministry of Education and Culture for funding the UNIPS project (Key Project OKM/199/523/2016), which enabled this study to be conducted and performed. Furthermore, they wish to thank all the study participants.

Funding The study was funded by the Ministry of Education and Culture (Finland), grant number OKM/199/523/2016, grant recipient University of Turku. However, the funding source had no involvement in study design, in the collection, analysis, and interpretation of data, nor writing the report or the decision to submit the article for publication.

\section{Compliance with ethical standards}

Conflict of interest The authors declare that they have no conflict of interest. All the authors have seen and agree with the contents of the manuscript and there are not any interests that might be interpreted as influencing the research. We certify that the submission is original work and is not under review at any other publication.

Open Access This article is distributed under the terms of the Creative Commons Attribution 4.0 International License (http://creativecommons.org/licenses/by/4.0/), which permits unrestricted use, distribution, and reproduction in any medium, provided you give appropriate credit to the original author(s) and the source, provide a link to the Creative Commons license, and indicate if changes were made.

\section{Appendix}

McNemar test results of the video interpretations within each course.

See Tables 10, 11 and 12 .

Table 10 Changes in interpretations in the videos pre- and post-participation in the course Becoming a Teacher

\begin{tabular}{llll}
\hline Post & $n$ & $p$ value \\
$n$ & & \\
$\operatorname{KT} n(\%)$ & $\operatorname{LF} n(\%)$ & & \\
\hline
\end{tabular}

Interpretation of the video 1
Pre
KT
\begin{tabular}{llrrr}
$6(19)$ & $7(23)$ & 31 & $.016^{\mathrm{a}}$ \\
LF & $0(0)$ & $18(58)$ & & \\
Interpretation of the video 2 & & & & \\
Pre & $8(30)$ & $9(33)$ & 27 & $.004^{\mathrm{b}}$ \\
KT & $0(0)$ & $10(37)$ & & \\
LF & & & & \\
\hline
\end{tabular}

${ }^{\mathrm{a}, \mathrm{b}}$ Binomial distribution used

$* p<.05, * * p<.01, * * * p<.001$

$K T$ knowledge transmission interpretation of teaching, $L F$ learning facilitation interpretation of teaching 
Table 11 Changes in interpretations in the videos pre- and post-participation in the course How to Plan My Teaching

Table 12 Changes in interpretations in the videos pre- and post-participation in the course Lecturing and Expertise

\begin{tabular}{|c|c|c|c|c|}
\hline & \multicolumn{2}{|l|}{ Post } & \multirow[t]{2}{*}{$n$} & \multirow[t]{2}{*}{$p$ value } \\
\hline & $\mathrm{KT} n(\%)$ & $\operatorname{LF} n(\%)$ & & \\
\hline \multicolumn{5}{|c|}{ Interpretation of video 1} \\
\hline \multicolumn{5}{|l|}{ Pre } \\
\hline KT & $7(21)$ & $6(18)$ & 33 & $.031^{\mathrm{a}}$ \\
\hline $\mathrm{LF}$ & $0(0)$ & $20(61)$ & & \\
\hline \multicolumn{5}{|c|}{ Interpretation of video 2} \\
\hline \multicolumn{5}{|l|}{ Pre } \\
\hline KT & $8(28)$ & $12(41)$ & 29 & $.000^{\mathrm{b}}$ \\
\hline $\mathrm{LF}$ & $0(0)$ & $9(31)$ & & \\
\hline
\end{tabular}

${ }^{\mathrm{a}, \mathrm{b}}$ Binomial distribution used $* p<.05, * * p<.01, * * * p<.001$

$K T$ knowledge transmission interpretation of teaching, $L F$ learning facilitation interpretation of teaching

\begin{tabular}{lllll}
\hline & \multicolumn{1}{l}{ Post } & $n$ & $p$ value \\
\cline { 2 - 3 } & KT $n(\%)$ & LF $n(\%)$ & & \\
\hline $\begin{array}{l}\text { Interpretation of video 1 } \\
\text { Pre }\end{array}$ & & & & \\
$\quad$ KT & $7(18)$ & $7(18)$ & 39 & $.016^{\mathrm{a}}$ \\
LF & $0(0)$ & $25(64)$ & & \\
Interpretation of video 2 & & & & \\
Pre & & & & \\
KT & $11(31)$ & $12(34)$ & 35 & $.000^{\mathrm{a}}$ \\
LF & $0(0)$ & $12(34)$ & & \\
\hline
\end{tabular}

${ }^{\mathrm{a}, \mathrm{b}}$ Binomial distribution used

$* p<.05, * * p<.01, * * * p<.001$

$K T$ knowledge transmission interpretation of teaching, $L F$ learning facilitation interpretation of teaching

\section{References}

Åkerlind, G. S. (2003). Growing and developing as a university teacher-Variation in meaning. Studies in Higher Education, 28(4), 375-390.

Akkerman, S. F. (2011). Learning at boundaries. International Journal of Educational Research, 50, 21-25.

Akkerman, S. F., \& Bakker, A. (2011). Boundary crossing and boundary objects. Review of Educational Research, 81(2), 132-169.

Ambrose, S., Huston, T., \& Norman, M. (2005). A qualitative method for assessing faculty satisfaction. Research in Higher Education, 46(7), 803-830.

Blomberg, G., Stürmer, K., \& Seidel, T. (2011). How pre-service teachers observe teaching on video: Effects of viewers' teaching subjects and the subject of the video. Teaching and Teacher Education, 27, 1131-1140.

Bullough, R. V., Jr., \& Knowles, J. G. (1991). Teaching and nurturing: Changing conceptions of self as teacher in a case study of becoming a teacher. International Journal of Qualitative Studies in Education, 4(2), 121-140.

Calderhead, J., \& Robson, M. (1991). Images of teaching: Student teachers' early conceptions of classroom practice. Teaching and Teacher Education, 7(1), 1-8. 
Carney, C., McGhee, D. V., Lee, J. D., Reyes, M. L., \& Raby, M. (2010). Using an event-triggered video intervention system to expand the supervised learning of newly licensed adolescent drivers. American Journal of Public Health, 100, 1101-1106.

Chalmers, D., \& Gardiner, D. (2015). An evaluation framework for identifying the effectiveness and impact of academic teacher development programmes. Studies in Educational Evaluation, 46, 81-91.

Chan, L. K., Patil, N. G., Chen, J. Y., Lam, J. C., Lau, C. S., \& Ip, M. S. (2010). Advantages of video trigger in problem-based learning. Medical Teacher, 32, 760-765.

Chi, M. T. (2009). Active-constructive-interactive: A conceptual framework for differentiating learning activities. Topics in Cognitive Science, 1, 73-105.

Chi, M. T., \& Wylie, R. (2014). The ICAP framework: Linking cognitive engagement to active learning outcomes. Educational Psychologist, 49, 219-243.

Dunekacke, S., Jen $\beta$ en, L., \& Blömeke, S. (2015). Effects of mathematics content knowledge on pre-school teachers' performance: A video-based assessment of perception and planning abilities in informal learning situations. International Journal of Science and Math Education, 13, 267-286.

Dunkin, M. J. (1990). The induction of academic staff to a university: Processes and products. Higher Education, 20, 47-66.

Elo, S., \& Kyngäs, H. (2008). The qualitative content analysis process. Journal of Advanced Nursing, 62(1), $107-115$.

Entwistle, N. (2009). Teaching for understanding at university: Deep approaches and distinctive ways of thinking. Basingstoke: Palgrave Macmillan.

Ertmer, P. (2005). Teacher pedagogical beliefs: The final frontier in our quest for technology integration? Educational Technology Research and Development, 53(4), 25-39.

European Commission. (2016). 941 final. Communication from the Commission to the European Parliament, the Council, the European Economic and Social Committee and the Committee of the Regions. Improving and modernising education. Brussels: European Commission.

Finnish Advisory Board on Research Integrity. (2019). The ethical principles of research with human participants and ethical review in the human sciences in Finland [PDF file]. Retrieved from https://www. tenk.fi/sites/tenk.fi/files/Ihmistieteiden_eettisen_ennakkoarvioinnin_ohje_2019.pdf

Fischer, D., \& Fick, C. (1993). Measuring social desirability: Short forms of the Marlowe-Crowne Social desirability scale. Education and Psychological Measurement, 53(2), 417-423.

Fox, D. (1983). Personal theories of teaching. Studies in Higher Education, 8, 151-163.

Fulmer, S. M., \& Frijters, J. C. (2009). A review of self-report and alternative approaches in the measurement of student motivation. Educational Psychology Review, 21, 219-246.

Gibbs, G., \& Coffey, M. (2004). The impact of training of university teachers on their teaching skills, their approach to teaching and the approach to learning of their students. Active Learning in Higher Education, 5, 87-100.

Gow, L., \& Kember, D. (1993). Conceptions of teaching and their relationship to student learning. British Journal of Educational Psychology, 63(1), 20-23.

Guskey, T. R. (2002). Professional development and teacher change. Teachers and Teaching: Theory and Practice, 8, 381-391.

Hanbury, A., Prosser, M., \& Rickinson, M. (2008). The differential impact of UK accredited teaching development programmes on academics' approaches to teaching. Studies in Higher Education, 33, 469-483.

Harteis, C., Fischera, C., Tönigesb, T., \& Wredeb, B. (2018). Do we betray errors beforehand? The use of eye tracking, automated face recognition and computer algorithms to analyse learning from errors. Frontline Learning Research, 6(3), 37-56.

Ho, A., Watkins, D., \& Kelly, M. (2001). The conceptual change approach to improving teaching and learning: An evaluation of a Hong Kong staff development programme. Higher Education, 42, 143-169.

Hsieh, H. F., \& Shannon, S. E. (2005). Three approaches to qualitative content analysis. Qualitative Health Research, 15(9), 1277-1288.

Kaiser, G., Busse, A., Hoth, J., König, J., \& Blömeke, S. (2015). About the complexities of video-based assessments: Theoretical and methodological approaches to overcoming shortcomings of research on teachers' competence. International Journal of Science and Mathematics Education, 13(2), 369-387.

Kane, R., Sandretto, S., \& Heath, C. (2002). Telling half the story: A critical review of the research on the teaching beliefs and practices of university academics. Review of Educational Research, 72(2), 177-228.

Kember, D., \& Kwan, K. (2000). Lecturers' approaches to learning and their relationship to conceptions of good teaching. Instructional Science, 28, 469-490.

Kersting, N. (2008). Using video clips of mathematics classroom instruction as item prompts to measure teachers' knowledge of teaching mathematics. Educational and Psychological Measurement, 68(5), 845-861. 
King, M., \& Bruner, G. C. (2000). Social desirability bias: A neglected aspect of validity testing. Psychology and Marketing, 17(2), 79-103.

Knight, P. (2002). Being a teacher in higher education. Buckingham: The Society for Research into Higher Education \& Open University Press.

Knight, P. T., \& Trowler, P. R. (2000). Departmental-level cultures and the improvement of learning and teaching. Studies in Higher Education, 25, 69-83.

Knorr-Cetina, K. (1999). Epistemic cultures: How the sciences make knowledge. Cambridge: Harvard University Press.

König, J., Blömeke, S., Klein, P., Suhl, U., Busse, A., \& Kaiser, G. (2014). Is teachers' general pedagogical knowledge a premise for noticing and interpreting classroom situations? A video-based assessment approach. Teaching and Teacher Education, 38, 76-88.

Laato, S., Salmento, H., \& Murtonen, M. (2018). Development of an online learning platform for university pedagogical studies-Case study. In Proceedings of the 10th international conference on computer supported education. Volume 2: CSEDU (pp. 481-488). Funchal: SCITEPRESS.

Levinson-Rose, J., \& Menges, R. J. (1981). Improving college teaching: A critical review of research. Review of Educational Research, 51, 403-434.

Light, G., \& Calkins, S. (2008). The experience of faculty development: Patterns in variation in conceptions of teaching. International Journal for Academic Development, 13, 27-40.

Lindblom-Ylänne, S., Parpala, A., \& Postareff, L. (2018). What constitutes the surface approach to learning in the light of new empirical evidence? Studies in Higher Education. https://doi. org/10.1080/03075079.2018.1482267.

Lindblom-Ylänne, S., Trigwell, K., Nevgi, A., \& Ashwin, P. (2006). How approaches to teaching are affected by discipline and teaching context. Studies in Higher Education, 31(3), 258-298.

Lipponen, L. (2002). Exploring foundations for computer supported collaborative learning. In G. Stahl (Ed.), Computer support for collaborative learning: Foundations for a CSCL community, Proceedings of the computer supported collaborative learning 2002 conference (pp. 72-81). Hillsdale: Erlbaum.

Lueddeke, G. R. (2003). Professionalising teaching practice in higher education: A study of disciplinary variation and 'teaching-scholarship'. Studies in Higher Education, 28, 213-228.

Marsh, H. W. (2007). Do university teachers become more effective with experience? A multilevel growth model of students' evaluations of teaching over 13 years. Journal of Educational Psychology, 99(4), 775-790.

Murray, K., \& Macdonald, R. (1997). The disjunction between lecturers' conceptions of teaching and their claimed educational practice. Higher Education, 33, 331-349.

Murtonen, M., \& Lehtinen, E. (in press). Adult learners and theories of learning. In E. Kallio (Ed.), Development of adult thinking: Perspectives from psychology, education and human resources. Routledge.

Murtonen, M., \& Ponsiluoma, H. (2014). Yliopistojemme tarjoamien yliopistopedagogisten opintojen historia ja nykyhetki [The history and current situation of offering pedagogical trainings in Finnish universities]. Yliopistopedagogiikka [Journal of University Pedagogy], 1, 7-9.

Norton, L., Richardson, J. T. E., Hartley, J., Newstead, S., \& Mayes, J. (2005). Teachers' beliefs and intentions concerning teaching in higher education. Higher Education, 50, 537-571.

Ödalen, J., Brommesson, D., Erlingsson, G. Ó., Karlsson Schaffer, J., \& Fogelgren, M. (2018). Teaching university teachers to become better teachers: The effects of pedagogical training courses at six Swedish universities. Higher Education Research \& Development, 38(2), 339-353.

Oleson, A., \& Hora, M. T. (2014). Teaching the way they were taught? Revisiting the sources of teaching knowledge and the role of prior experience in shaping faculty teaching practices. Higher Education, 68, 29-45.

Paavola, S., Lipponen, L., \& Hakkarainen, K. (2004). Models of innovative knowledge communities and three metaphors of learning. Review of Educational Research, 74(4), 557-576.

Paulhus, D. L., \& Vazire, S. (2007). The self-report method. In R. W. Robins, R. C. Fraley, \& R. F. Krueger (Eds.), Handbook of research methods in personality psychology (pp. 224-239). New York: The Guilford Press.

Postareff, L., Katajavuori, N., Lindblom-Ylänne, S., \& Trigwell, K. (2008a). Consonance and dissonance in descriptions of teaching of university teachers. Studies in Higher Education, 33(1), 49-61.

Postareff, L., \& Lindblom-Ylänne, S. (2008). Variation in teachers' descriptions of teaching: Broadening the understanding of teaching in higher education. Learning and Instruction, 18, 109-120.

Postareff, L., Lindblom-Ylänne, S., \& Nevgi, A. (2007). The effect of pedagogical training on teaching in higher education. Teaching and Teacher Education, 23, 557-571.

Postareff, L., Lindblom-Ylänne, S., \& Nevgi, A. (2008b). A follow-up study of the effect of pedagogical training on teaching in higher education. Higher Education, 56, 29-43. 
Postareff, L., \& Nevgi, A. (2015). Development paths of university teachers during a pedagogical development course. Educar, 51(1), 37-52.

Pratt, D. D. (1992). Conceptions of teaching. Adult Education Quarterly, 42, 203-220.

Prebble, T., Hargraves, H., Leach, L., Naidoo, K., Suddaby, G., \& Zepke, N. (2004). Impact of student support services and academic development programmes on student outcomes in undergraduate tertiary study: A synthesis of the research. Report to Ministry of Education, Massey University College of Education.

Prosser, M., Trigwell, K., \& Taylor, P. (1994). A phenomenographic study of academics' conceptions of science learning and teaching. Learning and Instruction, 4, 217-231.

Remmik, M., Karm, M., Haamer, A., \& Lepp, (2011). Early-career academics' learning in academic communities. International Journal for Academic Development, 16(3), 187-199.

Rienties, B., Brouwer, N., \& Lygo-Baker, S. (2013). The effects of online professional development on higher education teachers' beliefs and intentions towards learning facilitation and technology. Teaching and Teacher Education, 29, 122-131.

Samuelowicz, K., \& Bain, J. D. (1992). Conceptions of teaching held by academic teachers. Higher Education, 24, 93-112.

Samuelowicz, K., \& Bain, J. D. (2001). Revisiting academics' beliefs about teaching and learning. Higher Education, 41, 299-325.

Scardamalia, M., \& Bereiter, C. (2006). Knowledge building: Theory, pedagogy, and technology. In K. Sawyer (Ed.), Cambridge handbook of the learning sciences (pp. 97-118). New York: Cambridge University Press.

Seidel, T., Stürmer, K., Blomberg, G., Kobarg, M., \& Schwindt, K. (2011). Teacher learning from analysis of videotaped classroom situations: Does it make a difference whether teachers observe their own teaching or that of others? Teaching and Teacher Education, 27, 259-267.

Sherman, T. M., Armistead, L. P., Fowler, F., Barksdale, M. A., \& Reif, G. (1987). The quest for excellence in university teaching. Journal of Higher Education, 48, 66-84.

Steinert, Y., Mann, K., Centeno, A., Dolmans, D., Spencer, J., Gelula, M., et al. (2006). A systematic review of faculty development initiatives designed to improve teaching effectiveness in medical education: BEME Guide No. 8. Medical Teacher, 28(8), 497-526.

Stes, A., De Mayer, S., Gijbels, D., \& Van Petegem, P. (2012). Instructional development for teachers in higher education: Effects on students' learning outcomes. Teaching in Higher Education, 17(3), 295-308.

Stes, A., Min-Leliveld, M., Gijbels, D., \& Van Petegem, P. (2010). The impact of instructional development in higher education: The state-of-the-art of the research. Educational Research Review, 5, 25-49.

Stewart, M. (2014). Making sense of a teaching programme for university academics: Exploring the longerterm effects. Teaching and Teacher Education, 38, 89-98.

Teräs, H. (2016). Collaborative online professional development for teachers in higher education. Professional Development in Education, 42(2), 258-275.

Trigwell, K. (2002). Approaches to teaching design subjects: A quantitative analysis. Art, Design and Communication in Higher Education, 1(2), 69-80.

Trigwell, K., Caballero Rodriguez, K., \& Han, F. (2012). Assessing the impact of a university teaching development programme. Assessment \& Evaluation in Higher Education, 37(4), 499-511.

Trigwell, K., \& Prosser, M. (1996a). Congruence between intention and strategy in university science teachers' approaches to teaching. Higher Education, 32, 77-87.

Trigwell, K., \& Prosser, M. (1996b). Changing approaches to teaching: A relational perspective. Studies in Higher Education, 21(3), 275-284.

Trigwell, K., Prosser, M., \& Waterhouse, F. (1999). Relations between teachers' approaches to teaching and students' approaches to learning. Higher Education, 37(1), 57-70.

Uiboleht, K., Karm, M., \& Postareff, L. (2016). How do university teachers combine different approaches to teaching in a specific course? A qualitative multi-case study. Teaching in Higher Education, 21(7), 854-869.

Uiboleht, K., Karm, M., \& Postareff, L. (2018). The interplay between teachers' approaches to teaching, students' approaches to learning and learning outcomes: A qualitative multi-case study. Learning Environments Research, 21(3), 321-347.

Unipeda Support. (2017a). VIDEO 4 [Online video]. Retrieved from https://youtu.be/-c-6BBt5Hz0.

Unipeda Support. (2017b). VIDEO 6 [Online video]. Retrieved from https://youtu.be/kG2OMvRNb5Q.

Van Lankveld, T., Schoonenboom, J., Volman, M., Croiset, G., \& Beishuizen, J. (2017). Developing a teacher identity in the university context: A systematic review of the literature. Higher Education Research \& Development, 36(2), 325-342. 
Van Rossum, E. J., Deijkers, R., \& Hamer, R. (1985). Students' learning conceptions and their interpretation of significant educational concepts. Higher Education, 14(6), 617-641.

Vermunt, J. D., Vrikki, M., Warwick, P., \& Mercer, N. (2017). Connecting teacher identity formation to patterns in teacher learning. In D. J. Clandinin \& J. Husu (Eds.), The Sage handbook of research on teacher education (pp. 143-159). Los Angeles: SAGE Publications Ltd.

Vosniadou, S. (2013). Conceptual change in learning and instruction: The framework approach. In S. Vosniadou (Ed.), International handbook of research on conceptual change (pp. 9-30). New York: Routledge.

Vosniadou, S., \& Skopeliti, I. (2014). Conceptual change from the framework theory side of the fence. Science \& Education, 23(7), 1427-1445.

Weimer, M., \& Lenze, L. F. (1998). Instructional interventions: A review of the literature on efforts to improve instruction. In R. Perry \& J. Smart (Eds.), Effective teaching in higher education (pp. 205240). New York: Agathon Press.

Yadav, A., \& Koehler, M. (2007). The role of epistemological beliefs in preservice teachers' interpretation of video cases of early-grade literacy instruction. Journal of Technology and Teacher Education, 15(3), $335-361$.

Publisher's Note Springer Nature remains neutral with regard to jurisdictional claims in published maps and institutional affiliations. 